\title{
Suppliers ready to break rules
}

Washington

THE Office of Technology Assessment (OTA) of the US Congress has paid the international space industry the compliment of an economic analysis of its prospects not very different from what might be written about an established industry. In a report published this week, International Cooperation and Competition in Civilian Space Activities, OTA says that attempts at international collaboration will probably be blocked by national policies, but recommends that, wherever possible, governments should let space industries develop along unregulated lines.

Much of the report is meant to alert US industry to the emergence of competition in some space activities in other industrialized countries to which, the report says, US policies have not fully adapted. The report identifies the members of the European Space Agency (France in particular) and also Japan as the chief sources of competition during the coming decade.

Space activities are still predominantly within the domain of government, according to OTA. And the big spenders are the United States (which spent $\$ 17,500$ million in 1984 on civil and military applications) and the Soviet Union (which is said to have 600,000 people working in the field). US spending is 20 times that of the European Space Agency (ESA), and is the equivalent of 0.47 per cent of gross national product (GNP) compared with 0.08 per cent for France, the next in line.

OTA thinks it unlikely that there will emerge a competitive environment for trade in space-related services and products. "Since France and Japan... have made the decision to join the United States as space powers, it would be wishful thinking to believe that they will fully abide by the trade rules..."

Even within the United States, OTA is not convinced that there will be enough business to tempt private companies into the provision of launching vehicles, as three aerospace companies (Transpace carriers, General Dynamics and Martin Marietta) are in principle equipped to do. The report also says that the foreseeable demand for launching facilities is what it is at present - the need to put communications satellites in orbit - and that other satellite uses, such as for remote sensing and materials processing, "are even more uncertain".

The volume of demand should nevertheless be enough to keep both the US shuttle and Ariane fully occupied. According to figures compiled by Rockwell International and quoted by OTA, the combination of civil and military needs in the United States would be enough to occupy 24 shuttle flights a year by 1988 , with possible demand making necessary a further 20 flights a year in the succeeding five years. These calculations assume that Ariane would be making 10 flights a year from now on.

If these estimates are correct, OTA says, there may be a need for extra launching capacity by 1988 . But if the US defence needs are in part met by some other launching mechanism, either the shuttle or Ariane could be under-occupied between then and 1994. Those are the circumstances in which competition might occur.

At what price? The cost of a dedicated shuttle flight has already increased from the $\$ 18$ million estimated in 1975 to something like $\$ 80$ million now, but OTA points out that this is considerably less than the real cost of the five shuttle flights in 1983, which are estimated to have cost \$375 million each. By 1988 , when overhead costs will be spread over more launches, it may still be necessary to charge more than $\$ 100$ million for a dedicated launch.

At these rates, OTA says, the shuttle should still be cheaper than Ariane as a launching vehicle for geosynchronous satellites (which is reckoned to amount to $\$ 20,000$ for each pound of mass in orbit). But competition may be hindered by the terms on which launching services are offered; the US National Aeronautics and
Space Administration (NASA) is required to ask for all the cost in advance, but Ariane's managers take graduated payments.

OTA offers the US government a series of policy choices on the shuttle. If, the report says, the objective is to capture a large percentage of the commercial demand for satellite launchings, the result will probably be increased demand for use of the shuttle, perhaps even a need for more orbiting vehicles, and increased cost. If the US government were deliberately to encourage private US companies to enter the business, they would probably compete successfully with Ariane, but NASA's role as a space carrier would be reduced. The report also points out that a strategy intended to make the shuttle the vehicle to meet "all current and future" needs in the United States would greatly increase the cost of the shuttle programme and probably put Ariane out of business.

On the business of building communications satellites, OTA argues that US suppliers are the cheapest source of hardware (in spite of the strong dollar) and were able to compete successfully for the contracts to build all 20 of the Intelsat consortium satellites to be launched in the period 1984-89. But OTA notes that all 19 European satellites to be launched for European owners during the same period will be built in Europe, as will be the nine planned Japanese satellites to be built in Japan.

\section{US pharmaceuticals}

\section{Monsanto and Searle to merge}

\section{Washington}

THE planned merger of Monsanto and G.D. Searle, announced last week, will provide a quick shot in the arm for Monsanto's growing interest in drugs for human disease. The move will also give Monsanto access to a distribution network for pharmaceutical products, the development of which is one of the objectives of the recently expanded research facility at the company headquarters at St Louis, Missouri.

Although the Searle family, which at present owns 20 per cent of the stock in G.D. Searle, has made no secret of its wish to diversify its interest since last September, the planned merger appears to have taken the pharmaceutical industry by surprise. The plan is that Monsanto should offer to buy all the outstanding shares in G.D. Searle for a total cost of $\$ 2,700$ million.

The combined operation will have total sales of $\$ 8,000$ million a year, with Searle rather less than 20 per cent the size of Monsanto. Both businesses have substantial interests very different from their point of overlap in biotechnology, which appears to have been one of the chief reasons for the merger. Monsanto is primarily a manufacturer of plastics and agri- cultural and general chemicals, while Searle in the past two years has become, at least temporarily, the predominant supplier of the artificial sweeteners based on the di-amino acid aspartame.

Both companies have taken a close interest in biotechnology in the past few years. Searle, which has three major laboratories worldwide, has built up the laboratory at High Wycombe in Britain (with a complement of 600) to be a major centre of research in recombinant-DNA techniques. Monsanto's directly comparable interest is the somewhat smaller unit based at its Life Sciences Center at St Louis, opened formally only last year.

A spokesman for Searle said this week that the two research enterprises were likely only to reinforce each other. With the St Louis laboratory at the beginning of what is likely to be a period of growth and consolidation, the High Wycombe laboratory could well have the advantage of possession of the ground in any reorganization that comes about. But, formally, nothing can be done until Monsanto has made its formal offer for the shares of G.D. Searle, won the acceptance of a majority of the holders and then decided where it will raise the funds with which to pay for them.

John Maddox 